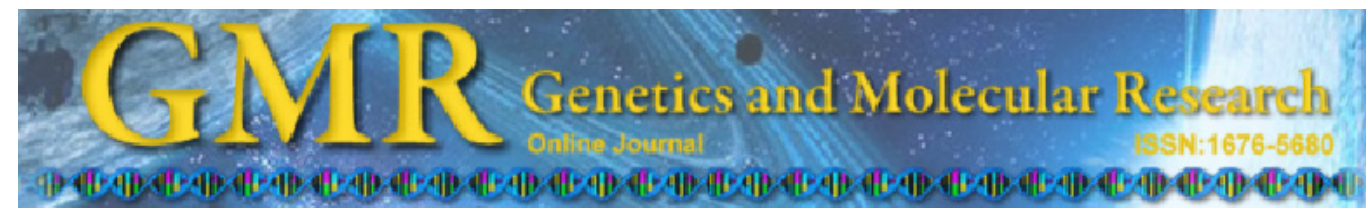

Short Communication

\title{
Isolation and characterization of polymorphic microsatellite loci in Aleurodicus dispersus (Hemiptera, Aleyrodidae)
}

\author{
G.-C. $\mathrm{Ma}^{1}$, X. Wu ${ }^{2}$, C.-L. Ma ${ }^{2}$, H.-L. Wu ${ }^{2}$, H.-Y. Hu${ }^{2}$, L.-M. Niu ${ }^{1}$ and \\ Y.-G. Fu ${ }^{1}$
}

${ }^{1}$ Key Laboratory of Monitoring and Control of Tropical Agricultural and Forest Invasive Alien Pests, Ministry of Agriculture, Environment and Plant Protection Institute,

Chinese Academy of Tropical Agricultural Sciences, Danzhou, Hainan, China ${ }^{2}$ Key Laboratory of Biotic Environment and Ecological Safety in Anhui Province, College of Life Sciences, Anhui Normal University, Wuhu, Anhui, China

Corresponding author: Y.-G. Fu

E-mail: fygcatas@163.com

Genet. Mol. Res. 10 (4): 2523-2526 (2011)

Received December 2, 2010

Accepted August 30, 2011

Published October 18, 2011

DOI http://dx.doi.org/10.4238/2011.October.18.2

\begin{abstract}
Ten microsatellite markers were isolated and characterized from Aleurodicus dispersus, the spiraling whitefly, an exotic pest species that is considered to be one of the most serious agricultural pests on Hainan Island, China. The polymorphism of these loci was examined in individual whiteflies from Hainan Island and from the Canary Islands. All loci were polymorphic, with two to four alleles per locus. Mean observed and expected heterozygosity values were 0.773 and 0.585 , respectively. These microsatellite markers provide powerful tools for ecological, epidemiological and population genetic studies on this highly invasive insect. Thirty insects were collected
\end{abstract}


and studied at each location. There were no differences between the two locations.

Key words: Aleurodicus dispersus; Microsatellite loci; Population genetics; Invasive insect

The whitefly, Aleurodicus dispersus (Russell, 1965), is an insect pest of many tropical and sub-tropical crops. It lays eggs in a typical spiral pattern, so it is more commonly known worldwide as 'spiralling whitefly'. This whitefly is native to the Caribbean region and Central America (Russell, 1965). The insect is highly polyphagous, and has been recorded on more than 100 plants belonging to 38 genera and 27 families, including many vegetables, ornamental and fruit crops (Waterhouse and Norris, 1989; Charati et al., 2003). In 2006, the spiralling whitefly was first detected in Lingshui, Hainan Province, China (E 110 02'26.8", N18 $31^{\circ} 52.4^{\prime \prime}$ (Yu et al., 2007). Since then, the whitefly has spread throughout Hainan Island and is considered to be one of the world's major agricultural pest groups (Han et al., 2008). Adults and nymphs of the whitefly cause direct feeding damage by piercing and sucking of sap from foliage. The "honeydew" excreted is a substrate for a sooty-mold fungus that interferes with photosynthesis, ultimately causing leaf shedding and reduced growth rate (Alam et al., 1998). The spiralling whitefly has a dramatic negative effect on the agricultural industry, causing a significant amount of monetary loss to these enterprises. Here, we report on the development 10 polymorphic microsatellite loci isolated from $A$. dispersus, which will be used to analyze the population genetics of $A$. dispersus.

The specimens of $A$. dispersus were sampled from Hainan Island and the Canary Islands. Adults were collected from the plants Pterocarpus indicus and Cocoloba uvifera and transferred to $1.5-\mathrm{mL}$ microcentrifuge tubes containing $95 \%$ alcohol, then taken to the laboratory and preserved at $-20^{\circ} \mathrm{C}$. To avoid microsatellite hemizygotes on the $\mathrm{X}$-chromosome, and amplification of Y-chromosomal rDNA, only females were selected for DNA extraction and subsequent analyses.

The method used for DNA extraction from whitefly individuals was described by Sambrook and Russell. A subgenomic library, enriched for microsatellites, was generated using a modified protocol described by Bloor et al. (2001). Total genomic DNA extracted from 15 whitefly individuals was digested with the restriction enzyme Sau3AI. Digested fragments were size-selected between 400 and $1000 \mathrm{bp}$ and were purified from a $1.2 \%$ TAE agarose gel using the Axygen Gel Extraction Kit. Double-stranded linkers (adaptorA: 5'-GGCCAGAGACCCCAAGCTTCG-3'; phosphorylated adaptorB: 5'-PO $\mathrm{PATCC}_{4}$ GAAGCTTGGGGTCTCTGGCC-3') were ligated to the digested DNA fragments. Biotinylated nucleotide probes $(\mathrm{AC})_{12},(\mathrm{AG})_{12}$ and (TTC $)_{8}$ (Sangon) were hybridized to the linker-ligated DNA. DNA containing nucleotide microsatellites were selectively selected using Streptavidin MagneSphere Paramagnetic Particles (Promega). Enriched fragments were recovered via polymerase chain reaction (PCR). Each PCR consisted of approximately $10 \mathrm{ng}$ microsatellite-enriched genomic DNA, 10X PCR buffer ( $200 \mu \mathrm{M} \mathrm{KCl}, 100 \mu \mathrm{M}$ Tris), $2.5 \mathrm{mM}$ each dNTP, $25 \mathrm{mM}$ $\mathrm{MgCl}_{2}, 10 \mu \mathrm{M}$ linker-F as primer, and $5 \mathrm{U}$ Taq DNA polymerase (TaKaRa). PCR amplifications consisted of $95^{\circ} \mathrm{C}$ for $5 \mathrm{~min}$, followed by 30 cycles of $95^{\circ} \mathrm{C}$ for $30 \mathrm{~s}, 60^{\circ} \mathrm{C}$ for $30 \mathrm{~s}$, and $72^{\circ} \mathrm{C}$ for $1 \mathrm{~min}$, and a final cycle of $10 \mathrm{~min}$ at $72^{\circ} \mathrm{C}$. PCR products were ligated into a pMD18-T vector (TaKaRa) and used to transform DH5 $\alpha$ competent cells. 
Of 480 screened colonies, 212 (44.2\%) were positive for nucleotide repeats. A large number of redundant clones were observed when sequencing all positive clones. Microsatellite primers were designed based on nucleotide sequence regions flanking microsatellites using the Oligo 6 software. A total of 32 PCR primer pairs were developed with 10 successfully amplifying microsatellite loci. These loci were tested in whitefly to determine if a polymorphic product could be reliably amplified and to determine the optimum annealing temperature. Fifteen-microliter PCRs consisted of 1-10 ng genomic DNA, 10X PCR buffer, $2.5 \mathrm{mM}$ of each dNTP, $25 \mathrm{mM} \mathrm{MgCl}, 10 \mu \mathrm{m}$ of each primer, and $5 \mathrm{U}$ Taq DNA polymerase (TaKaRa). The PCR amplification program was $95^{\circ} \mathrm{C}$ for $5 \mathrm{~min}$, followed by 30 cycles of $95^{\circ} \mathrm{C}$ for $30 \mathrm{~s}$, $50-60^{\circ} \mathrm{C}$ for $30 \mathrm{~s}, 72^{\circ} \mathrm{C}$ for $1 \mathrm{~min}$, and a final extension of $72^{\circ} \mathrm{C}$ for $7 \mathrm{~min}$. PCR products were resolved on $8 \%$ denaturing polyacrylamide gels (Wu et al., 2008) and 11 microsatellite loci were proved to be polymorphic (Table 1).

\begin{tabular}{|c|c|c|c|c|c|c|c|c|}
\hline Locus & Primer sequences $\left(5^{\prime}-3^{\prime}\right)$ & Repeat motif & $T_{\mathrm{a}}\left({ }^{\circ} \mathrm{C}\right)$ & Size range alleles (bp) & No. of alleles & $H_{\mathrm{o}}$ & $H_{\mathrm{E}}$ & GenBank No. \\
\hline AD2 & $\begin{array}{l}\text { F: CTCCATGCTGTTCTTGAT } \\
\text { R: CAGGCACCTATAAACCG }\end{array}$ & $(\mathrm{CT})_{16}$ & 53 & $251-275$ & 3 & 0.867 & 0.660 & HQ243664 \\
\hline AD3 & $\begin{array}{l}\text { F: CGACGATTTATACGAACGCA } \\
\text { R: ACACGAATTGAAGTTGAGGG }\end{array}$ & $(\mathrm{TC})_{20}$ & 53 & $241-261$ & 3 & 0.800 & 0.659 & HQ243665 \\
\hline AD5 & $\begin{array}{l}\text { F: CGTCTATTCTTACAGCCACA } \\
\text { R: ACCTGCCAGTAGTTTTGA }\end{array}$ & $(\mathrm{CT})_{22}$ & 53 & $248-252$ & 2 & 0.933 & 0.541 & HQ243666 \\
\hline AD12 & $\begin{array}{l}\text { F: TCACCAGACCCCACCCACCGAC } \\
\text { R: CACAAATGCTCCCAATACC }\end{array}$ & $(\mathrm{AC})_{11}$ & 53 & $242-246$ & 3 & 0.867 & 0.572 & HQ243667 \\
\hline AD13 & $\begin{array}{l}\text { F: CGACAACAGGAAACAACGGT } \\
\text { R: AAACTGGCAAAGGCGGAC }\end{array}$ & $(\mathrm{AG})_{11} \mathrm{GGAGG}(\mathrm{GA})_{10}$ & 55 & $308-320$ & 2 & 0.833 & 0.541 & HQ243668 \\
\hline AD15 & $\begin{array}{l}\text { F: CATTGAGTGGGTCCATTGTT } \\
\text { R: CGGGAAATGATGTCAGGAGG }\end{array}$ & $(\mathrm{TC})_{11} \mathrm{C}(\mathrm{TC})_{7}$ & 55 & $278-290$ & 4 & 0.767 & 0.767 & HQ243669 \\
\hline AD20 & $\begin{array}{l}\text { F: TGCGGGCTCCAACTATGT } \\
\text { R: TGTGGTCGGCAGGATTTA }\end{array}$ & $(\mathrm{CT})_{11}$ & 53 & 174-194 & 4 & 0.767 & 0.771 & HQ243670 \\
\hline AD21 & $\begin{array}{l}\text { F: CGTTGAATCCCTCTACTCT } \\
\text { R: GCTGCCATCTGTGAAATA }\end{array}$ & $(\mathrm{CT})_{20}$ & 53 & $149-151$ & 2 & 0.933 & 0.541 & HQ243671 \\
\hline AD23 & $\begin{array}{l}\text { F: GTAATGACCGTGCTAAGT } \\
\text { R: CTTTGAGATTTTGCGAGC }\end{array}$ & $(\mathrm{TCT})_{10}$ & 53 & $141-147$ & 3 & 0.867 & 0.669 & HQ243672 \\
\hline AD26 & $\begin{array}{l}\text { F: TTAAATTGCTCGCATGGC } \\
\text { R: TAAAATAGGCTTCAGACCC }\end{array}$ & $(\mathrm{TTC})_{14}$ & 53 & 191-194 & 2 & 0.100 & 0.129 & HQ243673 \\
\hline
\end{tabular}

Genepop version 3.4 (Raymond and Rousset, 1995) was used to estimate Hardy-Weinberg equilibrium (HWE) and linkage-disequilibrium of the 10 microsatellite loci. The observed heterozygosity $\left(H_{\mathrm{O}}\right)$ and expected heterozygosity $\left(H_{\mathrm{E}}\right)$ of each polymorphic locus were calculated using the CERVUS 2.0 program (Marshall et al., 1998). Furthermore, we used MicroChecker version 2.2.3 (van Oosterhout et al., 2004) to test for the presence of null alleles.

The number of alleles per locus ranged from 2 to 4 , with an average of 2.8 alleles per locus. The $H_{\mathrm{O}}$ ranged from 0.100 to 0.933 (mean $=0.773$ ), and the $H_{\mathrm{E}}$ from 0.129 to 0.771 $($ mean $=0.585)($ Table 1$)$. This low level of genetic variability may reflect the bottleneck effect associated with the introduction of this species to Hainan Island. Alternatively, insecticides used against $A$. dispersus could be implicated in selection pressure imposed by widespread use. After sequential Bonferroni's correction, significant deviation from HWE was not found in all loci. With the exception of AD2-AD3, AD15-AD20 and AD23-AD26 $(\mathrm{P}<0.05)$, none of the loci had significant linkage disequilibrium. 


\section{ACKNOWLEDGMENTS}

We wish to thank Dr. Estrella Hernández for providing samples from Instituto Canario de Investigaciones Agrarias. Research supported by the Special Fund for Agro-Scientific Research in the Public Interest (Grant \#201103026) and the National Natural Science Foundation of China (NSFC \#31071969). All experiments reported here comply with the current laws of China.

\section{REFERENCES}

Alam S, Islam MN, Alam MZ and Islam MS (1998). Effectiveness of three insecticides for the control of the spiralling whitefly Aleurodicus dispersili Rüssel, of guava. Bangladesh J. Entomol. 8: 53-58.

Bloor P, Barker FS, Watts PC and Noyes HA (2001). Microsatellite Libraries by Enrichment. School of Biological Sciences, University of Liverpool, Liverpool.

Charati SN, Pokharkar DS and Ghorpade SA (2003). Abundance of spiralling whitefly, a newly introduced pest in Maharashtra State. J. Maharashtra Agric. Univ. 28: 83-84.

Han DY, Liu K, Chen W and Fan ZW (2008). Distribution and host plants of spiralling whitefly, Aleurodicus dispersus, in Hainan. Chin. Bull. Entomol. 45: 583-588.

Marshall TC, Slate J, Kruuk LE and Pemberton JM (1998). Statistical confidence for likelihood-based paternity inference in natural populations. Mol. Ecol. 7: 639-655.

Raymond $\mathrm{M}$ and Rousset $\mathrm{F}$ (1995). GENEPOP (version 1.2): population genetics software for exact tests and ecumenicism. J. Hered. 86: 248-249.

Russell LM (1965). A new species of Aleurodicus Douglas and two close relatives (Homoptera: Aleyrodidae). Florida Entomol. 48: 47-55.

Sambrook J and Russell D (2001). Molecular Cloning: A Laboratory Manual. 3rd edn. Cold Spring Harbor Laboratory, New York.

van Oosterhout C, Hutchinson W, Wills D and Shipley P (2004). MICRO-CHECKER: software for identifying and correcting genotyping errors in microsatellite data. Mol. Ecol. Notes 4: 535-538.

Waterhouse DF and Norris KR (1989). Biological Control: Pacific Prospects: Supplement 1. Australian Centre for International Agricultural Research (ACIAR), Canberra.

Wu HL, Meng K and Zhu GP (2008). Isolation and characterization of microsatellite markers in black muntjac (Muntiacus crinifrons). Mol. Ecol. Res. 8: 584-586.

Yu GY, Zhang GL, Peng ZQ and Liu K (2007). The spiralling whitefly, Aleurodicus dispersus, invaded Hainan Island of China. China Bull. Entomol. 44: 42-43. 